\title{
Article
}

\section{The Role of Practice Educators in Initial and Post Qualifying Social Worker Education}

Stone, Clare

Available at http://clok.uclan.ac.uk/14525/

Stone, Clare ORCID: 0000-0001-7331-4244 (2016) The Role of Practice

Educators in Initial and Post Qualifying Social Worker Education. Social Work Education, 35 (6). pp. 706-718. ISSN 0261-5479

It is advisable to refer to the publisher's version if you intend to cite from the work. http://dx.doi.org/10.1080/02615479.2016.1185407

For more information about UCLan's research in this area go to http://www.uclan.ac.uk/researchgroups/ and search for < name of research Group>.

For information about Research generally at UCLan please go to http://www.uclan.ac.uk/research/

All outputs in CLoK are protected by Intellectual Property Rights law, including Copyright law. Copyright, IPR and Moral Rights for the works on this site are retained by the individual authors and/or other copyright owners. Terms and conditions for use of this material are defined in the policies page.

\section{CLoK}

Central Lancashire online Knowledge www.clok.uclan.ac.uk

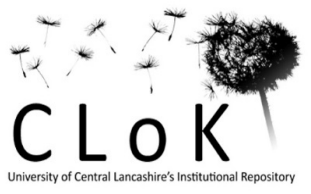


The Role of Practice Educators in Initial and Post Qualifying Social Worker

Education

\begin{abstract}
Doctoral research into competence for social work practice engaged with seventeen participants who drew upon their experiences of being practice educators and registered social work practitioners and the analysis of data suggested they identified a difference between competence to pass a final placement and capability for social work practice. Baseline social work knowledge, skills and values will enable a student to pass a final placement however, research data suggests that the individual's approach to learning, emotional intelligence and resilience give confidence that they are more likely to be able to cope in a social work role. Practice educators intuitively recognise these characteristics and this article argues that in addition to working with students, practice educators are ideally situated to support individuals throughout their post qualifying social work learning journey.
\end{abstract}

\title{
Abstract word count 129
}

Key words; Practice educators, competence, continuing professional development, resilience, emotional intelligence, and learning.

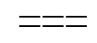

Declaration: this manuscript has not been published elsewhere and has not been submitted simultaneously for publication elsewhere. There are no disclosures or conflict of interests to note.

Word count excluding reference list $=4,771$ 


\section{Introduction}

In England practice educators are social work practitioners that supervise, teach and assess social work students on practice learning placements and make a recommendation to the awarding institution whether a student is 'fit to practise at the point of qualification' (SWRB, 2010:1). Those who complete a social work course in England, at either degree or masters level, may apply to the Health and Care Professions Council (HCPC) to enter the social work register which enables them to practise and use the title social worker (HCPC, 2012a). Outside of the UK the term often used for a practice educator is 'field educator' and the learning opportunity is called 'field education' rather than placement or practice learning placement which are preferred terms in England. Regardless of the title used, the practice educator, in partnership with the awarding institution, is situated as important in the training and 'gatekeeping' for the social work profession (Bogo, Regehr, Hughes, Power, \& Gioberman, 2002; Miller \& Koerin, 2001) to ensure that only those 'fit to practise' do graduate (Elpers \& FitzGerald, 2013; HCPC, 2012a:4).

The Practice Educator Professional Standards (PEPS) first came into effect in England in 2013 and were designed to outline the assessment and accreditation needed to support, teach and assess social work students (TCSW, 2012). The PEPS were followed by standards for Practice Development Educators (PDE) which were developed by a small working group 'accountable to TCSW's Professional Capabilities Framework (PCF) Review and Quality Assurance Group' (TCSW, Learn to Care, \& Care, 2013:1).

The PDE is a registered social worker who takes responsibility for supporting, assessing and/or supervising social workers undertaking post qualifying professional development and learning. This includes the Assessed and Supported Year in Employment (ASYE), Continuing Professional Development (CPD) programmes and activities, and Approved Mental Health Practitioner. (TCSW et al., 2013:1) 
For ease and to align this text with language currently used within the practice arena the term practice educator is used from this point on to refer to both practice educators who work with initial training students and the PDE who works alongside post qualified learners in the workplace. The first incarnation of a practice educator (then called a practice teacher) was introduced to social work education by The Central Council for Education and Training in Social Work (CCETSW, 1989) and despite the critical role they have played in social work education for almost three decades 'those supervising students in [social work placements] have generally been ignored in the research' (Gibson, 2012:54). Even with workplace learning and practice learning being considered to be the 'signature pedagogy' of social work (Larrison \& Korr, 2013) this element of social work education 'in general appears a relatively underdeveloped area of research' (Finch, 2009:24). Although the practice educator is situated as important in the gatekeeping for the social work profession and for ongoing continuous professional development their voices are rarely represented within empirical research. In particular how practice educators perceive competence for social work practice had not previously been researched in the UK before this doctoral research project set out to hear the voices of practice educators.

As practice educators make a recommendation to an awarding institution in relation to a student's capability for social work practice, judge ability during the first year in assessed practice and assess those training to become Approved Mental Health Practitioners insight into how they perceive competence is essential. This timely empirical research problematized the competence phenomenon and asked practice educators how they recognised competence for social work practice (Authors own work 2014). Phenomenological methodology was drawn upon to understand how practice educators construct the competence phenomenon. 


\section{Sample}

The Practice Educator Professional Standards outline the qualifications and experiences required to be a stage two practice educator which enables that practitioner to work with and assess a final year social work student on placement (TCSW, 2012). The purposive sample included seventeen stage two practice educators (or working towards stage two) who had experience of working with final year social work students. Participants were recruited through email invitation sent to them by practice learning coordinators in their employing social work agency. This process was considered important to ensure that no one felt obliged to take part in the research due to any existing or future relationships with the researcher. Ethical approval was obtained by the University's ethics committee, where the researcher was a doctoral student, before the recruitment process commenced. The seventeen participants who volunteered to be interviewed or to attend a card sort event represented all ages over 29 years, twelve identified as female and five as male gender. Twelve worked within local authority social work teams with the others employed within third sector agencies and practitioners worked across a range of service user groups including but not limited to children and families, mental health, learning disabilities and adult service. Two practice educators worked as freelance educators whilst the others were employed as social work practitioners by the agency in which the student placement was located. Collectively the sample of seventeen participants had 252 years of social work experience, 137 years as practice educators and had worked with 520 students and therefore were able to 'illuminate the phenomenon of' competence for social work practice (Ajjawi \& Higgs, 2007:616). 


\section{Method}

As the research aimed to interpret perspectives of the competence phenomenon from participants' lived experience data was generated in the first instance by way of semi structured interviews.

Participants were ask questions such as:

- What do you understand by the term 'fit in practice'?

- What do you think makes a student competent to practice social work?

- Do you find it easy to decide if a student is competent to practice social work / fit in practice?

- What do you take into consideration when making your decision?

- What sources of evidence do you use to inform your assessment?

- Have you ever passed a student as fit in practice and not been $100 \%$ sure that this is the case? If so please talk about this?

- What support /guidance / training needs do you have?

The interviews generated multiple examples of how practice educators described competence and capability for social work. These were collected together, similar statements compressed, paraphrased and where appropriate reworded (Ellingsen, Størksen, \& Stephens, 2010) to produce 36 statements. A card sort activity took place with practice educators where they were asked to rank the statement cards 'into a continuum of significance' (Jahrami, Marnoch, \& Gray, 2009:178). The aim was to establish whether practice educators considered some aspects of competence and capability to be more important than others. Examples of the cards include:

- Ability to do social work tasks

- Develop their own style of practice: not become a mini me 
- Build, maintain and progress professional relationships

- IT Skills

- Manage a small caseload

- Deal with crisis, recognise when a crisis is coming and plan for the future

- Ability to link theories they have learnt on the course to the practical application within placement

- Produce reports, documentation and paperwork

The event was similar to a focus group and the participants' discussions were captured on a voice recorder and were a useful 'spur for deeper and richer analysis' (Bloor, 1997:49; Ellingsen et al., 2010). This secondary method of engagement with research participants proved to be an important opportunity to review and check the developing understandings about practice educators' perspectives about competence and capability for social work practice.

Because 'phenomenology is interested in thinking, rather than behaviour, phenomenological analysis generates representation of perspectives rather than a description of what participants actually do in practice' (Stone, 2015:12). Therefore the interpreting and theorising offered through using Interpretative Phenomenological Analysis (IPA) (Smith, 1996) was considered to be more relevant to the research questions than traditional descriptive phenomenology (Pringle, Drummond, McLafferty, \& Hendry, 2011) because giving thought to the 'essence' of the phenomenon and exploring meaning moves the research beyond mere description (Dahlberg, 2006). As this research was concerned with individual perspectives and was not seeking to produce an objective statement about what competence is IPA was considered relevant (Giorgi \& Giorgi, 2008; Smith \& Osborn, 2008). A three stage IPA process was developed to engage with the data generated in this research (Authors own work 2015) which led to insight into how practice educators perceive competence for social work practice. 


\section{Findings}

\section{Passing a Final Placement Requires a Baseline of Social Work Knowledge, Skills and}

Values

When discussing the baseline to pass a final placement the practice educators described competencies and capabilities that fall within the domains of social work knowledge, skills and values which are all essential and are not of hierarchical significance. Knowledge is important as in addition to the student being able to follow instruction and perform set tasks the practice educators require them to be critical thinkers and cognitively engage with practice:

\footnotetext{
"but, I'd want to know that the thought was behind there too" (Alice)

"Understanding relevant legislation and relevant procedures such as safeguarding procedures" (Liam)

“Ability to link theory to practice and legislation" (Pamela)
}

The findings are that students need to know what they are doing and why. They need to use theory and knowledge of policies to inform practice. They also need academic ability to produce assessments, write reports and maintain records. The practice educators placed prominence on self-reflection and critical reflection in order that students will learn and develop.

The practice educators spoke of the range of skills needed to undertake comprehensive assessments, to intervene in service users' lives and to have well developed people skills to be able to work with service users, colleagues and other professionals. Dave works in learning 
disability services and recounts his experience of observing a student who was a skilled communicator:

\footnotetext{
"it was fabulous to see him on a one to one setting with people with a learning disability and how he could bring them out of their shell, how he could speak to them, how he could inspire them, how he got close to them, he had so many more skills, ... and being able to engage with people" (Dave)
}

Carl has been a social worker for eight years and supported students based within his own team and in the capacity as an offsite practice educator where the student's placement is within a different social work agency. He acknowledges some of the skills required to build and maintain relationships within mental health services:

\footnotetext{
"People skills, I think, because again, you're not going to get on with everyone I don't think, you're not going to please everyone, and that's not what we're here for. ... I guess, create some kind of rapport quite quickly, ...put people at ease, but also being able to ask the important questions, not being scared of asking questions" (Carl)
}

During interviews the practice educators refer to practical skills to do social work such as time management, ability to use a computer and being able to drive, however it was people skills that prominently featured in data. When explaining their views of competence to pass a final placement the practice educators also referred to values which underpinned social work knowledge and skills. They emphasised that competent practice is maintained by social work values and used phrases such as anti-oppressive and anti-discriminatory practice:

\footnotetext{
"I am also looking I suppose at anti-oppressive and anti-discriminatory practice especially in the field of mental health coz there's often a lot of stigma attached to someone with a mental illness" (Hazel)
}

However they also require students to match the team's values: 
"They seem to get into the similar work ethic and ethos that we have within our own environment and they seem to gel better within the team" (Dave)

When asked during interview about final year student competence the practice educators described characteristics and behaviours that fall within the categories of knowledge, skills and values. When asked to rank them into a continuum of significance the participants suggested that individual competencies are not hierarchical and a student must evidence holistic capabilities to pass a final placement.

\section{The Difference Between Passing a Final Placement and Competent Practice}

Practice educators find competencies helpful to provided structure to the practice learning placement and to the assessment, and they are particularly useful at the midpoint of placement where the student's progress can be reviewed and an action plan developed. However, although the student may have baseline knowledge, skills and values and thereby done enough to pass the final placement, this does not necessarily give the practice educator confidence that the student will go on to become a proficient social worker. The practice educators who participated in this research suggested there are additional qualities that they intuitively recognised in the more able students. The practice educators struggled to articulate these subliminal qualities (the extra factor) but the analysis of the qualitative data suggests that the student's approach to learning, emotional intelligence and resilience are the characteristics which practice educators consider important for social worker practice. 


\section{Approach to Learning}

The participants' statements about competence resonate with Knowles' principles of andragogy because the practice educators want students to be motivated to learn, are selfdirecting, and recognise and build upon prior experiences (Knowles, 1984):

\footnotetext{
"So I guess that's how I judge competence, are they asking questions, are they informed questions, are they finding their own answers" (Carl)

"I don't like students who are clock watching and want to go by the end of the day ... You'd want them to be keen and enthusiastic" (Alice)

"Whether they've got that thirst for knowledge and not just that tick box sort of culture" (Dave)
}

The practice educators are concerned by students who see the placement as a passive activity which echoes the work of Biggs and Tang (2007) who suggest that surface learners do just enough to meet the learning outcomes whereas deep learners engage on a cognitive level, ask questions and are active learners (Biggs \& Tang, 2007). The practice educators want students to engage in experiential learning, reflect and have the confidence to develop their own style as a practitioner.

\footnotetext{
"work alongside enough people to find the practice that suits them best. ... I'm a great believer in you have to watch other people work, because that's the only way you learn. And then they've got to develop their own practice from that and their own skill-base from that. . ... "cherry-picking, it's cherry-picking." (Karen)
}

A finding in this research is that the practice educators place great value on reflective practice for learning and professional development. This short extract from the interview with Pamela captures the views of many of the participants when she states that students ought to: 
The students need a reflective and lifelong approach to learning because social work is everchanging and what the students learn in their final year will need consolidating and extending:

"I am a great believer that you continue to learn however long you have been doing it" (Hazel)

"It's to prepare students for the first social work role... where the learning journey continues" (Rose)

"because the new world is grossly different to my world five years ago, now it's all about real intensive safeguarding investigations (Liam)

The practice educators look beyond the immediate placement when they consider whether an individual has the capability to become and effective practitioner. If a student approaches the placement as an opportunity to learn and is motivated to continue their learning the practice educator considers they will be better prepared for social work after the initial qualifying course.

\section{Emotional Intelligence}

The practice educators who participated in this research place great significance on students who have higher levels of emotional intelligence. Emotional intelligence can be defined as the ability to read our own and other people's emotions and to handle ourselves and our interventions with others appropriately (Goleman, 2004a, 2004b; Howe, 2008; Mayer, Caruso, Panter, \& Salovey, 2012). Karen recognises the intrapersonal aspect of emotional intelligence:

"in the person. ...It's that knowing who they are, it's that knowing that you can..." (Karen)

Rose uses Douglas' phrase 'tuning in' to describe both the intra and inter-personal aspects required for working with service users (Douglas, 2008:382): 
"perceptive tuning in is more than empathy... ...that insightfulness... it's that business about tuning in...getting alongside...it is really difficult to describe and yet when you see a student whose got it you know" (Rose)

It is important for the student to be self-aware, to work alongside both service users and colleagues. This is articulated by Liam who asks of students:

\footnotetext{
“can they work with multi-agency professionals, what's the communication like what's their actual team working like amongst a team, what's the communication like with service users" (Liam)
}

Dave who works within learning disability services talks positively about a student who used both verbal and nonverbal communication:

"and I notice that on one occasion, he got down, he got right down, just to get that face contact with them, he didn't labour the point, he put them at their ease" (Dave)

An individual with emotional intelligence can say the right thing; know when to say nothing and appropriately offer comfort (Howe, 2008). The literature on emotional intelligence describes the elements of knowing oneself and being able to read, understand and interact successfully with others. In this research the practice educators highlight the significance of all of these elements of emotional intelligence. They spoke in positive ways about students who were able to communicate with a range of people and develop professional working relationships. It would appear that practice educators consider an individual requires emotional competence to become a good social worker.

\section{Resilience}

The participants in this research spoke of three sources of pressure that social workers face on a daily basis. First working with people who use social work services can be challenging and social workers can face hostility, aggression and frequently practice in traumatic situations. 
Social work clients are often vulnerable, oppressed and face discrimination and working to support such individuals is stressful. A second source of pressure comes from working within a social work agency where there is high levels of staff turnover, resource constraints, exceedingly high caseloads and lack of supportive supervision. A third source of pressure can come from the individual's private life and this can impact on professional performance. To work within these three layers of pressure and inducers of stress an individual needs to develop a resilient identity. Resilience is being able to adapt to internal and external stressors (Collins, 2007) and is 'the ability to recover rapidly after experiencing some adverse experiences' (Saarni, 2000:81). Resilience is a term often used in social work practice as it is 'emotionally and morally demanding' and practitioners need resilience and strategies to cope (Morrison, 2007:14). During the interviews participants repeatedly spoke about how difficult and challenging social work practice is. This example from Fiona who works in child protection is one of many stories outlining how social workers require resilience:

\footnotetext{
"you're working with not enough resources, working with challenging service users, well it's common isn't it, situations of risk, social workers do get assaulted and killed ...cope with stress and not have too many periods of sickness its important" (Fiona)
}

In this extract Rose suggests that the work is traumatic but she is able to recognise students who will become capable practitioners:

\footnotetext{
“As a children's guardian that's all you do, work with trauma all the time... There are some qualities you seen in some students where you think yes you could work through this trauma and manage all that" (Rose)
}

Liam claims that due to workload pressures in the adult protection team he receives an inadequate level of supervision:

"I get supervised once every six months" (Liam) 
Liam went on to expresses frustration with a student who lacked resilience:

“my student didn't come in one day because she was tired and she rang me and said I'm exhausted so I'm not coming in" (Liam)

The practice educators express concern that some students do not seem to cope well in social work environments because they do not have resilience. Jenny and Jean work as freelance educators and they both said that students without resilience "become like service users". The practice educators draw upon their experience that many newly qualified workers have high caseloads and often receive inadequate levels of support and supervision. Resilience is required to do the very difficult job of social work, in social work agencies and despite what is occurring in one's private life they have to turn up for work and give it one hundred per cent.

\section{Discussion}

The practice educators who participated in this research concur with those in Furness and Gilligan's (2004) research that meeting the outcomes for initial social work training does not necessarily equate to confidence in the individual's ability to undertake competent social work practice (Furness \& Gilligan, 2004). The ‘qualification-competence gap’ outlined by Eraut (1998) is illustrated by the research participants who construct a space between completing a final placement and becoming a social worker (Eraut, 1998:130). Illustration 1. represents the baseline social work knowledge, skills and values that a student must have to pass a final placement but their approach to learning, emotional intelligence and resilience is recognised by practice educators as essential for competent social work practice post qualification. The six segments together are required and by clearly naming these characteristics an opportunity is created for academics and practice educators to engage in dialogue about how best to support 
the development of competence both during initial training and in post graduate professional development.

Illustration1. Six segments of competence

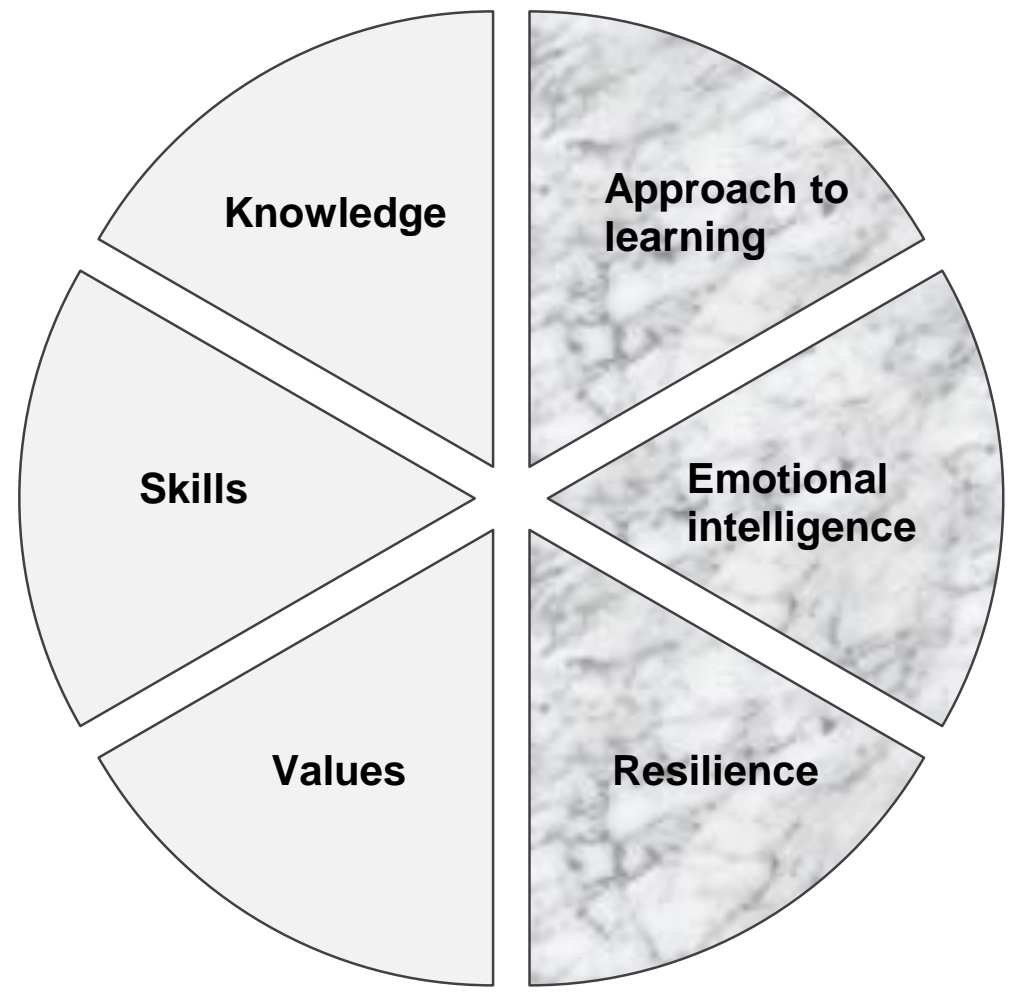

At the point of data collection the National Occupational Standards for Social Work (NOS) (TOPSS, 2002) were being phased out and the Professional Capabilities Framework (PCF) (TCSW, 2013) and Standards of Proficiency (SOP) (HCPC, 2012b) were being introduced. A student's approach to learning, emotional intelligence and resilience were not represented within the NOS but all three appear within the PCF and SOP which means they are directly applicable to both initial and post graduate social work education. For example the SOP requires individuals to 'understand both the need to keep skills and knowledge up-to-date and the importance of career-long learning' (SOP 3.3) and the PCF asks that individuals 'demonstrate a commitment to your continuous learning and development' (PCF 1.9). In 
relation to resilience the SOP requires social workers to 'be able to manage the physical and emotional impact of their practice' (SOP 3.5) and the PCF refers to resilience in general terms and also identifies the importance of emotional resilience: 'with support, take steps to manage and promote own safety, health, wellbeing and emotional resilience' (PCF 1.1).

As learning, resilience and emotional intelligence are all now included within the assessment frameworks for social work, educators have a responsibility to directly asses them. However they must also take responsibility for supporting learners to develop within these areas. Therefore practice educators must focus attention onto all six segments of competence as illustrated (illustration 1).

Because one's approach to learning, resilience and emotional competence are not fixed attributes educators can support the development of each during initial training and during post qualifying learning in the workplace. Although research has shown that the foundations for emotional intelligence are laid in childhood this is not a fixed trait and individuals can learn and develop emotional competence. Goleman (2004) talks of the brain needing retooling and Howe (2008) describes the brain as 'plastic' but they both agree that it takes time to change emotional responses, behaviour and feelings (Goleman, 2004b; Howe, 2008). The practice learning placement and workplace experiential learning are ideal opportunities to practise and fine tune emotionally competent responses because the learner usually receive one to one tailored teaching and support from their practice educator.

Like emotional intelligence, resilience is not a fixed attribute and can be altered positively or negatively (Carson, King, \& Papatraianou, 2011; Collins, 2008; Grant \& Kinman, 2013). Practice educators can support social workers to develop resilience 'by adding resources, bolstering and improving relationships and coaching people to develop skills that build self-efficacy' (Lishman, 2007:2005). Practice educators can provide feedback and help individuals to recognise when they have successfully coped with a difficult situation because 
this develops skills and internal confidence in their abilities which ultimately bolsters selfefficacy (Wilks \& Spivey, 2010). Armed with new knowledge, skills and confidence the student or practitioner approaches future situations from a stronger 'more secure' position of internal resilience (Payne, 2011:12).

The role of the practice educator is crucial as social workers need regular, nurturing and reflective supervision to develop emotions and optimism to help 'establish and maintain resilience' (Collins, 2007:266). However the development of emotional intelligence and resilience both require the learner to be engaged and motivated and to keep going despite setbacks and challenges. They must work in partnership with the educator, take responsibility for their learning and engage in reflection to make changes to their practice. Urdang (2010) suggests that 'being self-reflective builds clinical competence, can help prevent burnout and boundary violations' and even suggests 'self-reflectiveness' can protect the social worker from client violence' (Urdang, 2010:536). However reflective practice can be challenging and therefore requires motivation and a deeper approach to learning. A student must want to learn and develop because very strong motivation is required for transformative learning (Illeris, 2002). Strong motivation is a cornerstone of a deep approach to learning but rather than conceptualising deep and surface learning as fixed binary positions it is more constructive to see them as a metaphor illustrating a continuum along which a learner can be supported to move. Therefore rather than label an individual as either a deep or a surface learner the educator can develop their 'teaching to elicit an active response from students' (Biggs \& Tang, 2007:25). Practice educators can draw upon traditional and more contemporary learning theory to actively engage students and practitioners in transformative learning (Authors own work 2016). For example adopting a strengths approach is useful within teaching because the learner is supported to become more self-aware and able to identifying strengths which are important aspects within emotional intelligence, resilience and approaches to learning (Oko, 2011; Wei- 
he \& Ming-sum, 2010). Modelling is also an effective learning device for social work practice and therefore practice educators need to become good role model (Barretti, 2007; Mumm, 2006). Wilson's research concluded:

\begin{abstract}
'Perhaps one of the most important messages for educators is the need to ensure that students gain direct experience of observing good professional practice and positive role models in order to facilitate their reflective learning and professional socialisation.'
\end{abstract} (Wilson, 2013:168)

Those working alongside social work learners must model engagement with social work knowledge, skills and values but also in their approach to learning, emotional competence and demonstrate their resilience to work within social work settings. On-going feedback and reflective supervision are also important teaching aids and there are many other epistemological tools and techniques that can be drawn upon to support professional development. The aim for practice educators must be to motivate individuals to become engaged lifelong learner who are reflective and thereby learn from their experiences and improve their practice because 'the professional self is continually reassessed and evolves' beyond initial training (Larrison \& Korr, 2013:201).

In addition to supporting, teaching and assessing social work students there is an important role for practice educators with post qualifying learners in the workplace. The practice educator needs to consider the development of knowledge, skills and values and also those characteristics required to be a safe and effective social worker: resilience, emotional intelligence and a continuous motivated engaged adult learner. It is therefore suggested that the practice educator has a relevant and meaningful role in the ongoing transformative learning for social work practice. 


\section{Conclusion}

In this empirical research practice educators differentiate the borderline social work students from those they consider more likely to become effective practitioners by their approach to learning, resilience and emotional intelligence. These three domains (alongside social work knowledge, skills and values) span across initial training and into post qualifying social work practice and this article suggests that practice educators can have a meaningful role in working with practitioners to sustain development within these areas. By understanding that they are not fixed attributes practice educator can draw upon learning strategies, offer reflective supervision and support the practitioner learner in their ongoing transformative learning. The role of the Practice Development Educator (PDE) is still quite new and is not at this point in time a mandatory role yet they are well positioned to make a substantial contribution to education within and for social work practice. Practice educators (and PDE) are ideally situated to support individuals during initial training and throughout an individual's post qualifying social work learning journey. 


\section{Bibliography}

Ajjawi, R., \& Higgs, J. (2007). Using Hermeneutic Phenomenology to Investigate How Experienced Practitioners Learn to Communicate Clinical Reasoning. Qualitative Report, 12(4), 612-638.

Barretti, M. A. (2007). Teachers and Field Instructors as Student Role Models: A Neglected Dimension in Social Work Education. Journal of Teaching in Social Work, 27(3-4), 215-239.

Biggs, J., \& Tang, C. (2007). Teaching for Quality Learning at University: What the Student Does (3rd Edition). Buckingham: Open University Press.

Bloor, M. (1997). Techniques of validation in qualitative research: a critical commentary. In G. Miller \& R. Dingwall (Eds.), Context and method in qualitative research. London: Sage.

Bogo, M., Regehr, C., Hughes, J., Power, R., \& Gioberman, J. (2002). Evaluating A Measure Of Student Field Performance In Direct Service: Testing Reliability And Validity Of Explicit Criteria. Journal of Social Work Education, 38(3), 385-401.

Carson, E., King, S., \& Papatraianou, L. H. (2011). Resilience Among Social Workers: The Role of Informal Learning in the Workplace. Practice (09503153), 23(5), 267-278.

CCETSW. (1989). Improving standards in practice learning : regulations and guidance for the approval of agencies and the accreditation and training of practice teachers: CCETSW, 1989.

Collins, S. (2007). Social workers, resilience, positive emotions and optimism. Practice: Social Work in Action, 19:4(4), 255-269.

Collins, S. (2008). Statutory Social Workers: Stress, Job Satisfaction, Coping, Social Support and Individual Differences. British Journal of Social Work, 38(6), 1173-1193.

Dahlberg, K. (2006). The essence of essences-The search for meaning structures in phenomenological analysis of lifeworld phenomena. International Journal of Qualitative Studies on Health and Well-being, 1(1), 11-19.

Douglas, H. (2008). Preparation for Contact: An Aid to Effective Social Work Intervention. Social Work Education, 27(4), 380-389.

Ellingsen, I. T., Størksen, I., \& Stephens, P. (2010). Q methodology in social work research. International Journal of Social Research Methodology: Theory \& Practice, 13(5), 395409.

Elpers, K., \& FitzGerald, E. A. (2013). Issues and Challenges in Gatekeeping: A Framework for Implementation. Social Work Education, 32(3), 286-300.

Eraut, M. (1998). Concepts of competence. Journal of Interprofessional Care, 12(2), 127-139.

Finch, J. L. (2009). Can't Fail, Won't Fail - Why Practice Assessors Find it Difficult to Fail Social Work Students. A Qualitative Study of Practice Assessors' Experiences of Assessing Marginal or Failing Social Work Students. Professional Doctorate in Social Work Thesis. University of Sussex.

Furness, S., \& Gilligan, P. (2004). Fit for purpose: issues from practice placements, practice teaching and the assessment of students' practice. Social Work Education, 23(4), 465479.

Gibson, M. (2012). Narrative Practice and Social Work Education: Using a Narrative Approach in Social Work Practice Education to Develop Struggling Social Work Students. Practice (09503153), 24(1), 53-65.

Giorgi, A., \& Giorgi, B. (2008). Phenomenology. In J. A. Smith (Ed.), Qualitative Psychologh. A practical Guide to Research Methods (2nd ed.). London: Sage. 
Goleman, D. (2004a). Emotional Intelligence. Why it can matter more than IQ (Vol. Omnibus edition). London: Bloomsbury.

Goleman, D. (2004b). Working with Emotional Intelligence (Vol. Omnibus edition). London: Bloomsbury.

Grant, L., \& Kinman, G. (2013). 'Bouncing Back?' Personal Representations of Resilience of Student and Experienced Social Workers. Practice (09503153), 25(5), 349-366.

HCPC. (2012a). An Introduction To Our Education Processes. London: Health and Care Professions Council.

HCPC. (2012b). Standards of proficiency. Social work in England. London: Health and Care Professions Council.

Howe, D. (2008). The emotionally intelligent social worker Basingstoke: Palgrave Macmillan.

Illeris, K. (2002). The three dimensions of learning : contemporary learning theory in the tension field between the cognitive, the emotional and the social Frederiksberg: Roskilde University Press; Leicester: Niace Publications.

Jahrami, H., Marnoch, G., \& Gray, A. M. (2009). Use of card sort methodology in the testing of a clinical leadership competencies model. Health Services Management Research, 22(4), 176-183.

Knowles, M. S. (1984). Andragogy in action. London: Jossey-Bass.

Larrison, T. E., \& Korr, W. S. (2013). Does Social Work Have a Signature Pedagogy? Journal of Social Work Education, 49(2), 194-206.

Lishman, J. (2007). Handbook for practice learning in social work and social care (2nd ed.). London: Jessica Kingsley.

Mayer, J. D., Caruso, D. R., Panter, A. T., \& Salovey, P. (2012). The Growing Significance of Hot Intelligences. American Psychologist, 67(6), 502-503.

Miller, J., \& Koerin, B. B. (2001). Gatekeeping in the Practicum: What Field Instructors Need to Know. Clinical Supervisor, 20(2), 1.

Morrison, T. (2007). Emotional intelligence, emotion and social work: Context, characteristics, complications and contribution. British Journal of Social Work, 37(2), 245-263.

Mumm, A. M. (2006). Teaching Social Work Students Practice Skills. Journal of Teaching in Social Work, 26(3/4), 71-89.

Oko, J. (2011). Understanding and using theory in social work. (2nd ed.).Exeter: Learning Matters.

Payne, M. (2011). Risk, Security and Resilience Work in Social Work Practice. Social Work Review / Revista de Asistenta Sociala(1), 7-14.

Pringle, J., Drummond, J., McLafferty, E., \& Hendry, C. (2011). Interpretative phenomenological analysis: a discussion and critique. Nurse Researcher, 18(3), 20-24.

Saarni, C. (2000). Emotional Competence. A Developmental Perspective. In R. Bar-On \& J. D. A. Parker (Eds.), Handbook of emotional intelligence : the theory and practice of development, evaluation, education, and implementation - at home, school, and in the workplace: San Francisco, Calif.: Jossey-Bass.

Smith, J. A. (1996). Beyond the divide between cognition and discourse: using interpretative phenomenological analysis in health psychology. Psychology \& Health, 11(2), 261271.

Smith, J. A., \& Osborn, M. (2008). Interpretative Phenomenological Analysis. In J. A. Smith (Ed.), Qualitative psychology : a practical guide to research methods.(2nd ed.). London: Sage.

Stone, C. (2015). Developing method to meet the needs of the research. Journal of International Doctoral Research, 4. number 1.

SWRB. (2010). Practice Educator Professional Standards for Social Work. http://www.education.gov.uk/swrb/education.shtml: Social Work Reform Board. 
TCSW. (2012). Practice Educator Professional Standards and Guidance (Vol. Edref5 V1.0 May 2012). $\quad$ http://search.collegeofsocialwork.org/search/search.cgi?collection=sciecosw\&query=PRACTICE\%20EDUCATORS.

TCSW. (2013). The Professional Capabilities Framework. Retrieved 08/02/2013

TCSW, Learn to Care, \& Care, S. f. (2013). Social Work Practice Development Educators. http://www.skillsforcare.org.uk/Social-work/Social-work-CPD/Continuing-todevelop-social-workers.aspx.

TOPSS. (2002). The National Occupational Standards for Social Work. England: Topss.

Urdang, E. (2010). Awareness of Self-A Critical Tool. Social Work Education, 29(5), 523538.

Wei-he, G., \& Ming-sum, T. (2010). From resilience to resistance: A reconstruction of the strengths perspective in social work practice. International Social Work, 53(2), 233245.

Wilks, S. E., \& Spivey, C. A. (2010). Resilience in Undergraduate Social Work Students: Social Support and Adjustment to Academic Stress. Social Work Education, 29(3), 276288.

Wilson, G. (2013). Evidencing Reflective Practice in Social Work Education: Theoretical Uncertainties and Practical Challenges. British Journal of Social Work, 43(1), 154-172. 